for behandling av de vanligste psykiske lidelsene gjennomgås. Kapitlene er oversiktlige og inneholder en kort gjennomgang av klinikk, retningslinjer for behandling og monitorering, behandling av spesielle populasjoner, bivirkninger og interaksjoner. Dette er gjort på en svært kortfattet og god måte, og det er redegjort for prinsipper for fornuftig bruk av psykofarmaka. Polyfarmasi er en svært utbredt, men dårlig dokumentert, praksis i psykiatrien. En påminnelse om hvordan opptrapping, monitorering og ev. bytte av legemiddel bør skje, kan være nyttig for mange klinikere.

Denne håndboken vil imidlertid ha begrenset interesse for helsearbeidere som arbeider i Norge. Utvalget av legemidler som omtales, er for lite, og til dels ikke i tråd med norske anbefalinger og klinisk praksis. I kapitlene om angst og søvnforstyrrelser omtales f.eks. kun benzodiazepiner. Man får imidlertid en kortfattet og grei gjennomgang av en del psykofarmakologiske prinsipper. Boken kan være et nyttig arbeidsredskap for helsearbeidere som skal arbeide $i$ land med begrensede ressurser $\mathrm{i}$ helsevesenet, der behandlingen må ses med andre øyne.

\section{Godt oppslagsverk om patofysiologi}

Silbernagl S, Lang F.

Color atlas of pathopysiology

2. utg. 448 s, tab, ill. Stuttgart: Thieme, 2010. Pris EUR 35

ISBN 978-3-13-116552-7

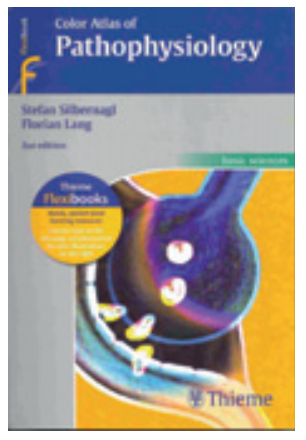

To fremtredende tyske fysiologer har skrevet denne boken. De mange og svært gode illustrasjonene er utarbeidet i nært samarbeid med to grafiske designere, Rüdiger Gay og Astried Rothenburger.

I alt er det ti kapitler. I det første omtales cellevekst, intracellulær signalering og apoptose. Forfatterne gir også en kort, men god omtale av tumorcellevekst og metastasering. Deretter følger kapitler om temperaturregulering, metabolisme og hormoner. Alle kapitlene starter med en oversikt, så følger en omtale av enkelttilstander og patofysiologi. Boken er gjennomgående godt skrevet og vil være et nyttig oppslagsverk, men den er like mye et bildeatlas med helsides illustrasjoner på så godt som annenhver av de nærmere 400 sidene.

Etter de innledende, mer generelle kapitlene følger kapitler om lunge, nyre, gastrointestinaltraktus, hjerte, sirkulasjon, muskel og sensorisk nervesystem. I alle kapitlene er det korte, presise gjennomganger av patofysiologi knyttet til sykdom i de respektive organsystemene.

Teksten er presis, og det er lagt vekt på at fremstillingen skal være kort. Formatet er hendig, slik at boken kan være lett tilgjengelig som oppslagsverk. Det er tatt høyde for at noen av kapitlene kan være knappe, ved at det på slutten er lagt til et eget kapittel med anbefalinger for mer omfattende, videre lesning og studier.

Målgruppen er studenter, leger under utdanning og seniorer. Dette er andre utgave. Første utgave kom i 1998 og var da skrevet på tysk. Boken er nå oversatt til en rekke språk, inklusive engelsk, fransk, japansk, portugisisk, tsjekkisk og gresk.

\section{Ansgar 0. Aasen}

Institutt for kirurgisk forskning

Oslo universitetssykehus, Rikshospitalet

\section{Ord kan drepe}

Schjenken E.

\section{Jeg er ingen rasist}

157 s, Oslo: Aschehoug, 2009. Pris NOK 329

ISBN 978-82-03-29165-4

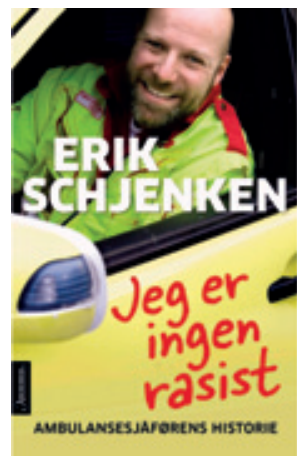

Jeg anbefaler at alle som arbeider $\mathrm{i}$ helsevesenet leser denne boken. Det er fordi Erik Schjenken innvier leseren i det som er allehelsearbeideres mareritt: A stille en feil diagnose blir likestilt med å ha gjort en dårlig jobb. Og enda

verre: at svikten skyldes rasisme.

Mange års innsats i helsetjenesten og tusenvis av vel gjennomførte utrykningsoppdrag blir overskygget av arbeidet utført i Sofienbergparken i Oslo i minuttene fra 17.13 til 17.20 mandag 6 . august 2007 . De to ambulansesjåførene ble i mange medier beskyldt for å forlate en bevisstløs pasient.

Påstanden var feil. Pasienten var ikke på noe tidspunkt bevisstløs. Schjenken er sterkt kritisk til at Oslo legevakt ikke avkreftet denne påstanden. Hjerneskaden ble først konstatert ved CT på Ullevål to timer senere. Han ble lagt i medisinsk koma.
Schjenken erkjenner at de to ambulansesjåførene oppfattet pasienten som et ordensproblem pga. det de tolket som hans viljestyrte urinering på ambulansepersonellet. Uttrykkene «din jævla gris», «din tulling» og «toget er gått» blir da ikke rasistiske, men forståelige, om ikke akseptable.

To tilbakeholdte informasjoner bidro til at inntrykket av rasisme ble skapt og lenge opprettholdt: At pasienten hadde urinert på ambulansepersonellet ble ikke opplyst pga. taushetsplikten til helsepersonell. At fotografier av pasienten som sto oppreist da ambulansen forlot stedet ikke ble gjengitt av mediene, er vanskeligere å forstå. Et foto av pasienten liggende på bakken ble kåret til «Årets bilde».

Man behøver ikke være persepsjonsekspert for å forstå at slik selektiv rapportering forsterker ønskede tolkninger: at ambulansepersonellet var rasistiske. Korsfest! Korsfest! De mange som hadde behov for å få bekreftet sin renhet og godhet, inntok vel innøvde, bebreidende posisjoner og øste ut sin moralske aggresjon. Ettersom det var forestående valg, kom fire statsråder straks på banen, og daværende finansminister tok teten. Først ble ambulansetjenesten stigmatisert og karakterisert med uttrykk som få våger å bruke mot minoriteter. Snart var rasisme et problem $i$ hele helsevesenet og deretter i alle offentlige tjenester.

Schjenkens beretning viser at personfokusert medieomtale ofte er uetterrettelig, av og til også dypt urettferdig og ytterst krenkende og derfor kan representere en helserisiko. Han fikk viktig støtte av sine kolleger og en kanskje avgjørende hjelp av en psykiater. Arbeidsgiveren kommer ikke pent fra det. «Tie-og-tåle»-tradisjonen som helsepersonell følger, betyr at personen må forholde seg passiv, og eventuelle tilsvar begrenses av taushetsplikten. Å ta til motmæle som Erik Schjenken og tidligere helsedirektør Anne Alvik nå har gjort, er nyttig for at sakene endelig blir belyst. De personlige belastningene blir begripelige for oss andre, men blir de det for angriperne?

Olav Gunnar Ballo har bedt Anne Alvik om unnskyldning for sin urimelige kritikk. Er det på tide at noen ber Erik Schjenken og hans kollega om unnskyldning? Når skal NRK be forskerne bak hjertestansprosjektet på Ullevål om unnskyldning? Når skal kolleger slutte å uttale seg om kolleger basert på et medieskapt virkelighetsbilde? Kanskje bedre å ta en telefon og spørre kollegaen: «Hva i all verden er dette?» Når er det tillatt å heve taushetsplikten?

Erik Schjenken skal ha en varm takk for at han deler sine bitre tårer med oss.

\section{Lars Weisæth}

Nasjonalt kunnskapssenter om vold og traumatisk stress

Universitetet i Oslo 